\title{
Rizal, The Social Portraitist
}

\author{
Emmanuel Jeric A. Albela \\ The Graduate School and Department of History \\ University of Santo Tomas, Manila, Philippines \\ eaalbela@ust.edu.ph \\ https://orcid.org/0000-0002-0023-7951
}

Antonio C. Hila

The Graduate School, University of Santo Tomas, Manila, Philippines

tonioan47@yahoo.com

\begin{abstract}
This paper attempts to direct on how to understand the two famous novels of Rizal - Noli Me Tangere and El Filibusterismo - within the context of Rizal's intent to expose the social ills of his time. With the use of Charles Derbyshire's translations of The Social Cancer and The Reign of Greed, the researchers explain and show the essential details of the novels and how they reflect historical, social realities as exposed in literary terms - using allegory as synthesis. It includes a re-assessment of the characters in both novels, the key places in the story, conflicts, and how these conflicts are resolved towards the end. The study conveys how Rizal expressed his reflections on and critique of the Philippine society through character and institutional symbolisms. Using historical hermeneutics as a method of the study, the researcher will keep an eye on the available sources and collections of literature, thereby putting the novels in their proper contexts, which properly define Rizal as a novelist and a social critic.
\end{abstract}

Keywords: Rizal, Noli Me Tangere, El Filibusterismo, Portraitist, Novelist, Philippines

Date Submitted: March 26, 2020

Date Revised: June 6, 2020

Date Accepted: June 15, 2020

\section{Introduction}

The novels of Jose Rizal, the Noli Me Tangere and El Filibusterismo are considered as the way to understand his ideas and thoughts, a gateway to reflect about the Philippine society during his time. These novels faced several criticisms, especially from the Catholic Church, because of Rizal's attacks against frailocracy. ${ }^{1}$ Nevertheless, these

\footnotetext{
${ }^{1}$ The term frailocracy or frailocracia is literally translated as friar rule. This refers to the vast power the friars amassed in the religious and political realms. This is discussed at length by the reformist Marcelo $\mathrm{H}$. Del Pilar in his biting essay, see Frailocracy in the Philippines, trans Leonor Agrava (Manila: National Historical Institute, 2009). For easy reference on the "Reform Movement" and its anti-friar sentiment, see Teodoro
} 
novels were also defended from such attacks by Rizal's friends and compatriots.

These novels (especially Noli Me Tangere) were marked as subversive. They said to contain heresy in projecting a degrading image of the church. A careful reading of these works leads to the discovery of Rizal's way of thinking. Several studies have already been written to give the public better ways to understand the novels, thereby revealing Rizal's political thoughts, and perhaps even his philosophy. Accordingly, Rizal's thought is conveyed by his works, either as allegorical or political, which both uphold ideals that Rizal possibly acquired from his education, as well as his experience of the local and global events in the nineteenth century. His educational background, both in the Philippines and later in Europe, resounds in the two novels. Given his European liberalism experience, the novels manifest his ideology and, consequently, his account of the Philippine society under Spain's governance.

This paper is an attempt to elucidate the critical areas on how to understand the novels, which leads to an evaluation if Jose Rizal was effective in portraying the condition of the Philippines by using allegory. Through it, this paper also paves the way towards Rizal's version of causality in the history of the country.

\section{Intellectual Background of Rizal}

Jose Rizal was born in the mid-19th century, which was a time of enormous global change. His education in Ateneo Municipal de Manila with the Jesuits exposed him to the wonders of arts and sciences, and in the University of Santo Tomas through philosophy and medical sciences. When he studied in Universidad Central de Madrid, Rizal was more exposed to the growing spirit of European Liberalism. His studies and the experience of European society made him recognize the enormous inequality in the speed of development between the Philippines and Spain. ${ }^{2}$

Rizal's European exposure notably includes his familiarity with the growth of philosophical thoughts in Europe. The Enlightenment in Germany (the Enlightenment or Aufklärung had been the prevalent school or movement in Germany in the $17^{\text {th }}$ and $18^{\text {th }}$ centuries). The existence of philosophers in France shaped the intellectual development of Rizal. They can be said to be reflected in his novels, Noli Me Tangere and El Filibusterismo. Prominent in these works are the ideas of progress and freedom, wherein freedom is posed as an essential component of progress. ${ }^{3}$ Hence, his exposure to the philosophies of different thinkers, such as Kant et al. (year?), is inevitably magnified and reflected in his works.

The intellectual atmosphere in which Rizal found himself in late 19th century Europe $^{4}$ helped him to set the parameters, characterization, personification, and flow

\footnotetext{
Agoncillo and Oscar Alfonso's History of the Filipino People, (Quezon City, Malaya Books, 1967): 150-179. Friar's rule is explicitly seen in Rizal's Noli Me Tangere, specifically in Chapter XX - "The Meeting in the Town Hall," where the wishes of the curate prevailed. This moved the sage Tasyo, speaking to Ibarra in Chapter XXV - "In The House of the Sage" to say: "The government has no dream of a healthy future; it is the arm, while the head is the convento." See Jose Rizal, The Social Cancer, trans. Charles Derbyshire (Manila: McCullough Printing Company, 1974): 120-12; 160.

2Petronilo Daroy, "The Ideas of European Liberalism in the Fiction of Rizal." Philippine Social Sciences and Humanities Review no.3 (June 1965): 129.

${ }^{3}$ Raul J. Bonoan, S.J., "An Inquiry in Rizal's Prophetic Vision." The Noli Me Tangere A Century After: An Interdisciplinary Perspective (1987): 8.
}

${ }^{4}$ Bonoan, S.J., "Rizal's Prophetic Vision," 1. 
of the story in his novels. This atmosphere, in fact, already transpired even before Rizal wrote his novels. In his speech giving honor to the two Filipino artists: Juan Luna, who won a gold medal (out of 3) for his masterpiece Spoliarium and Félix Resurrección Hidalgo who won a silver medal (out of 45) in 1884 for the Madrid Exposition, Rizal said:

The patriarchal age is getting to an end in the Philippines; the illustrious deeds of the sons [of the country] are no longer accomplished within its boundaries; the Oriental chrysalis is breaking out of hits sheath; brilliant colors and rosy streaks herald the dawn of a long day for those regions, in that race, plunged in lethargy during the night of its history while the sun illumined other continents, awakes anew, shaken by the electric convulsion produced by contact with western peoples, and demand light, life, the civilization that was once it is a heritage from time, thus confirming the eternal laws of constant evolution, periodic change, and progress. You know this well and you glory in it; the diamonds that shine in the Crown of the Philippines owe their beauty to you; she gave the uncut stones, Europe their polished facets. And all of us behold with pride, the finished work, and we the flame, the spirit, and raw material we have flourished. ${ }^{5}$

These words mark Rizal's rhetoric as he wanted to imply the growth of the Filipinos in the past centuries of Spanish colonization. Here, it is clear that Rizal thinks Filipinos like Luna, Hidalgo, and himself were just like the Spaniards who can be renowned across the world regardless of race and homeland. Implicitly, it is as though Rizal advocated that genius knew no race or citizenship, and he called for equal treatment with the Spaniards.

For Rizal, the paintings of Luna (Spoliarium) and Hidalgo (Christian Virgins Exposed to the Mob), embodied, "the essence of our social, moral and political life: humanity in severe ordeal struggle with prejudice, fanaticism, and injustice..." ${ }^{6}$ So, even before writing the novels, the fruits of European Liberalism were already present in Rizal's mind. He was aware of the injustices caused by Spain to his native land. Thus, it will be as if the events and his implicit appeals transcribed in his novels.

\section{The Novels}

The Noli Me Tangere was published in 1887 in Berlin, Germany, before the end of his first sojourn in Europe. Three years after, its sequel El Filibusterismo published in Ghent, Belgium, right before he decided to leave Europe for the second time, but this time, for good. These novels are considered Jose Rizal's most famous works. They would become very important masterpieces of Philippine literature in depicting the Philippine social scenario during the Spanish Regime. The novels classified as socio-historical novels show us the ways and morals of the people - of both the natives and the Spanish rulers, which faithfully portrayed and ridiculed the evils regnant in Philippine society. ${ }^{7}$

${ }^{5}$ Leon Ma Guerrero, The First Filipino: A Biography of Jose Rizal, (Manila: Guerrero Publishing, 1991), 114.

${ }^{6}$ Guerrero, The First Filipino, 114.

${ }^{7}$ See Teodoro Agoncillo's "Literature as History," p. 48 and "The Historical Background of Philippine Literature," p. 93 in History and Culture, Language and Literature: Selected Essays of Teodoro Agoncillo." ed. Bernardita Reyes-Churchill (Manila: UST Publishing House, 2003). 
With how the Enlightenment movement and European liberalism influenced Rizal, these novels surely are products of his critical mind.

Although classified as pieces of literature, the two novels could not be considered to tell a particular story, but in general, would contain adequate storylines. In Noli, Rizal exposed the frailocracy of the country and the shortcomings of the officials in the government. It is a novel of both social and political criticism with satiric commentaries on a vast range of colonials and natives. ${ }^{8}$ In the Fili, Rizal exposed the evils of society. In this novel, Rizal asserted to cast-off anarchy and reverted to his previous thought that going through a political disaster was the only way for the Filipinos to deserve freedom.

In reading and understanding the two novels, Rizal puts progressive education as the dominant theme. Rizal clearly expressed the importance of education by releasing the tyranny in the Philippines. His novels always speak for its significance by using the characters and institutions in his novels. It is believed that whatever modifications Rizal made later about his juvenile ideas of education, the sense of the importance of education in the development of the society remained with him and continued to be the central basis of his idea of reform. ${ }^{9}$ That he could merely propose enlightenment through education. ${ }^{10}$

As mentioned earlier, these works are socio-historical novels, meaning, it is a reflection of social, historical realities as exposed in literary terms - using allegory as its synthesis. Using irony and ridicule with the dexterity of an expert swordsman, which he was, Rizal won the praises of the Filipino community in Spain but the cankered hatred of the clerical party whose misdeeds were delineated with a faithfulness that his Spanish critics' denials and denunciations failed to undermine. ${ }^{11}$ In both novels, Rizal presented the general idea of a community that was suffering from illness. As we recall the life of Rizal, he was a physician in practice. However, he would always have a passion for Philosophy and Letters. He made use of his artistic writing skills by using medical terms. In Noli Me Tangere, Rizal uses naturalism as a referent to achieve two literary aims: to present an irony and to suggest the resolution he intended to fulfill. ${ }^{12}$ His motive in writing the Noli, as he wrote in the dedication part of his novel:

[...]Thus, how many times, when in the midst of modern civilizations I have wished to call thee before me, now to accompany me in memories, now to compare thee with other countries, hath thy dear image presented itself showing social cancer like to that other

Desiring thy welfare, which is our own, and seeking the best treatment. I will do with thee that ancients did with their sick, exposing them on the steps of the temple so that everyone who came to invoke the Divinity might offer them

${ }^{8}$ Elliot C. Arensmeyer, "Little Mansions: Some Aspects of Jose Rizal as a Novelist," Philippine Studies 18, no.4 (October 1970): 743.

9Daroy, "European Liberalism," 113.

${ }^{10}$ Florentino H. Hornedo. "Noli Me Tangere: Creating an Idiom to Legitimize a New Paradigm of Power." The Noli Me Tangere A Century After: An Interdisciplinary Perspective (1987): 86.

${ }^{11}$ Teodoro Agoncillo. "The Historical Background of Philippine Literature," 93.

${ }^{12}$ Daroy, "European Liberalism," 133. 
a remedy. ${ }^{13}$

Rizal implied that the body politic is diseased with cancer, of which he wanted to seek a cure. For him, writing the novel was his way of seeking the best treatment "exposing them on the steps of the temple..." It is also observed that Rizal followed the law of nature, growth, of evolution, and of the corresponding vitality of society and politics and culture by involvement with the desires and intentions of people living the actuality of that society, that politics, this culture: Rizal's concern inevitably accreted into an intelligible representation. Daroy strengthens such claim: literature does acquire a greater interest and significance - life is more important. ${ }^{14}$ In giving these, we can say that Rizal's other reason in writing this novel was his love for his country. ${ }^{15}$ As for the $E I$ Filibusterismo, meanwhile, he propounds the issues related to the liberalism of the $19^{\text {th }}$ century. ${ }^{16}$ This is made evident as Rizal chose the norms of realism and naturalism - the main influxes of liberalism in Europe.

The novels mirrored the Philippines' social realities through its places and character that Rizal used to present the conflict between liberalism and frailocratic authoritarianism. ${ }^{17}$ The characters were also noted to have their allusions or equivalents in the real-life scenario. In his letter (in French) dated March 1887, Rizal wrote:

"The incidents I relate are all true, and they happened; I can give proofs of them. My book will have, and it has defects from the artistic and aesthetic point of view. I do not deny it, but what cannot be questioned is the impartiality of my narration." ${ }^{18}$

For Carlos Quirino, such allusions affirmed the novels' authenticity. These novels were all based in reality, and one good point here is that the characters themselves were based on real people who lived in the country at that time. Rizal used these characters to present social cancer in Noli and how this disease may have found its cure, as he developed some of the characters in Fili towards its end.

\section{The Characters, Interpretations, and Symbols}

The two novels, Noli Me Tangere and El Filibusterismo, represent the cultural realities of the Philippine society. This was the reason why Rizal claimed that in Noli Me Tangere, Filipinos could see their history for the past ten years. The novels hold that each of the dramatis personae represents a cultural institution or social movement at play in Philippine society at the time of Rizal. ${ }^{19}$ Since Rizal himself provided representations to each of the characters in his novels, Rizal scholars will have to deepen the discourse and expand the course of interpretation. Carlos Quirino, in Noli and Fili: Their Historical Authenticity published by The Historical Bulletin (June 1963), discussed the historical figures that can be found in the novels of Rizal. The major characters, even the places placed in the novel, had their allusions in reality. He said that the Calle Anloage was initially a street called anluwagi-a tribute to the carpenters in the area where the house

\footnotetext{
${ }^{13} J o s e$ Rizal, The Social Cancer, trans. Charles Derbyshire (Manila: McCullough Printing Company, 1974), vii. ${ }^{14}$ Daroy, "European Liberalism," 136.

${ }^{15}$ see Rizal's "El Amor patrio."

${ }^{16}$ Daroy, "European Liberalism," 150.

${ }^{17}$ Hornedo, "Creating an Idiom," 82.

${ }^{18}$ Carlos Quirino, "Noli and Fili: Their Historical Authenticity," Historical Bulletin 7 (June 1963): 137.

${ }^{19}$ Ricardo R. Pascual, "Institutional Interpretation of Rizal's Novels." University College Journal 5-6 (1964): 78.
} 
of Capitan Tiago was located. Today, this street is named after Juan Luna. The town San Diego, for Quirino, is the birthplace and hometown of Rizal-Calamba in the province of Laguna. Both places mentioned in the novel are said to represent the Philippines as we trace how these places have been relevant to the characters.

Ricardo Pascual pointed out that in the novels, "institutionally interpreted, such narrative would symbolize the historical situation that the culture represented by the married couple's experience was that of pre-Spanish, Philippines, which, from anthropological observations and judgments therefrom, would be without the promising future represented by an heir."20 This means that each of the characters and places played a role in presenting the condition of Philippine society. Each character and place also represented an institution to give us an overview of the society, culture, and history of the country with the use of symbols.

Let us first take the house of Capitan Tiago. In the first chapter, Rizal described his house:

[...] "Capitan Tiago was considered one of the most hospitable of men, and it was well known that his house, like his country, shut its doors against nothing except commerce and all new or bold ideas." 21

The house of Capitan Tiago is open to all except for "commerce and all-new bold ideas," which can be interpreted as the development of capitalist economy and the instruction of science (liberal education), which can bring enlightenment to the Philippines. It can be noted that Rizal formulated the constitution of Liga Filipina to lead the Filipinos to be involved in commerce and secure the nation's material prosperity. Here, the house of Capitan Tiago represents the Philippines under Spain that keeps on resisting development and preserves ignorance. By keeping the Philippines shunned from the blessings of science and liberty, there would be continuous blind obedience to the Spanish bureaucracy in the islands. However, Rizal also had his observation to the house, in the same chapter, here was his further description:

"The house of which we are speaking is somewhat low and not exactly correct in all its lines: whether the architect who built it was afflicted with poor eyesight or whether the earthquakes and typhoons have twisted it out of shape, no one can say with certainty."22

Rizal was also aware that Spain at that time was facing many internal and external problems. The late $19^{\text {th }}$ century was Spain's waning moment as a world power. In the Philippines, the Spanish colonial government debauched the money paid by the natives. The budget for 1880-1881, for example, showed that the government earned $\mathrm{P} 14,630,486.01$, while its expenditure amounted to $\mathrm{P} 16,477,198.01$, which meant a deficit of $\mathrm{P} 1,846,712.01 .^{23}$ Spain faced many such difficulties that soon it would fall as a world power. Fr. Miguel Bernad, S.J. pointed this in his study about Humor and Craftsmanship in the Opening Chapters of Noli and Fili, he said:

\footnotetext{
${ }^{20}$ Pascual, "Interpretation of Rizal," 79.

${ }^{21}$ Rizal, The Social Cancer, 1.

${ }^{22}$ Rizal, The Social Cancer, 2.

${ }^{23}$ Teodoro Agoncillo, "Prelude to a Revolution."
} 
The friar remarks critical of the governor-general, which the officer is quick to resent; he is even quicker to stop an allusion that the friar is about to make to the illegitimate birth of the reigning monarch in Spain. Rizal is here alluding not only to the Spanish dynastic troubles but also to their divisive effects in Manila, where the friars were, in general, said to be politically inclined towards the Carlist cause. $^{24}$

In Noli, during the dinner in Chapter II, it is observable that most of the people seated at the dining table was the important, rich, if not, powerful in the society, while the servants were placed a little too far from it. This indicates that as one becomes more distant to the dining table, the lower is one's status in society. The social status is more definite in Fili. In Chapter I - On the Upper Deck where one finds how Rizal described the decks in the steamer Tabo:

"Moreover, if the comparison with the Ship of State is not yet complete, note
the arrangement of the passengers. On the lower deck appear brown faces
and black heads, types of Indians, 1 Chinese, and mestizos, wedged in between
bales of merchandise and boxes, while they are on the upper deck, beneath an
awning that protects them from the sun, are seated in comfortable chairs a few
passengers dressed in the fashion of Europeans, friars, and government clerks,
each with his puro cigar, and gazing at the landscape apparently without heeding
the efforts of the captain and the sailors to overcome the obstacles in the river."

Rizal was very keen on class distinction. This can be further observed in Chapter XLIX in Noli, with Ibarra during his conversation with Elias:

"I don't know who you are, but I suspect that you are not a man of the people; you think and act so differently from others. You will understand me if I tell you that, however imperfect the condition of affairs maybe now, it would be more so if it were changed. ${ }^{26}$

Here, Ibarra was telling Elias that he is also in the same class with him, that what he represents (tulisanes) was not like him because he thinks differently. Another interesting scene in Noli that deals with the class distinctions is in Chapter XI The Rulers:

[...]"Well, if he offers you chocolate which I doubt-but if he offers it remember this: if he calls to the servant and says, 'Juan, make a cup of chocolate, eh!' then stay without fear; but if he calls out, 'Juan, make a cup of chocolate, ah!' then take your hat and leave on the run."

"What!" the startled visitor would ask, "does he poison people? Carambas!"

"No, man, not at all!"

"What then?"

\footnotetext{
${ }^{24}$ Miguel A. Bernad, S.J, "Humor and Craftsmanship in the Opening Chapters of the Noli." Noli Me Tangere A Century After: An Interdisciplinary Perspective (1987): 46.

${ }^{25}$ Jose Rizal, The Reign of Greed, trans Charles Derbyshire (Manila: McCullough Printing Company, 1974), 2.

${ }^{26}$ Rizal, The Social Cancer, 312.
} 
“'Chocolate, eh!' means thick and rich, while 'chocolate, ah!' means watered and thin." ${ }^{27}$

The symbol used here was the kind of chocolate drink that will be offered to a person. For the rich and important ones, it should be chocolate, eh-espeso, thick. For ordinary people, it should be chocolate ah-aguado, watered.

The major characters in the novels played an important role in symbolizing the institutions that could be found in Philippine society. Each character represents a cultural quality that magnifies a Filipino trait in Rizal's time.

Let us first take the case of Maria Clara. Maria Clara culturally exhibited, as the novel portrayed her, a strong religious leaning, being fathered by a man who belonged to a dominant religious institution - the Catholic Church - and noticeable underpinnings of perseverance and modesty, buttressed by faithfulness to a decision made - characteristics contributed by the native percentage. ${ }^{28}$ According to Pascual, Maria Clara represents one of the powerful institutions in the country, the Catholic Church. On the other hand, we have Juan Crisostomo Ibarra, an allusion of Rizal, and a symbol of an intellectual, a trait that should lead the national movement in forming the national community. Florentino Hornedo stated how Rizal described the characterization of the two, "He preferred the drama of the rich Juan Crisostomo Ibarra and Maria Clara. He preferred them as a vehicle for his challenge to the powerful in the Philippines of the time... it was the conflict between liberalism and frailocratic authoritarianism." 29

Elias is another major character in the novel that helped the plot grows towards the end of the story. His conversations with Ibarra were Rizal's way of bringing out his political ideas and revealing the country's social ills. Ibarra was said to be Rizal himself. Wenceslao Retana, biographer of Rizal could not agree that Elias was another Rizal in the novel, but Miguel de Unamuno said otherwise:

\begin{abstract}
"Retana insists that Rizal is the Ibarra but not the Elias of Noli Me Tangere. I think that he both Ibarra and Elias, and this is especially true when they contradict each other. Because Rizal himself is the spirit contradiction, a soul that dreads the revolution, although deep within himself he consummately desires it: he is a man who at the same time both trusts and distrusts his countrymen and racial brothers; who believes them to be the most capable and yet the least capable - the most capable when he looks at himself as one of their blood; the most incapable when he looks at others. Rizal is a man who constantly pivots between fear and hope, faith and despair."30
\end{abstract}

Elias could be the alter-ego of Crisostomo Ibarra. Rizal used these two characters to put his political views. He also had a problem with himself, in using the characters-whether to choose reform or revolution. In Chapter XLIX The Voice of the Hunted, the political ideas of Rizal revealed:

\footnotetext{
${ }^{27}$ Rizal, The Social Cancer, 64.

${ }^{28}$ Pascual, "Interpretation of Rizal," 79-80.

${ }^{29}$ Hornedo, "Creating an Idiom," 82.

${ }^{30}$ Miguel de Unamuno, "Rizal: The Tagalog Hamlet." trans Antonio Molina in Rizal: Contrary Essays, ed. Petronilo Daroy (Quezon City: Guro Books, 1968): 8.
} 
"Sir," replied Elias gravely, "I am the bearer of the wishes of many unfortunates."

"Unfortunates? What do you mean?"

In a few words, Elias recounted his conversation with the leader of the tulisanes, omitting the latter's doubts and threats. Ibarra listened attentively and was the first to break the long silence that reigned after he had finished his story.

"So they want-"

"Radical reforms in the armed forces, in the priesthood, and the administration of justice; that is to say, they ask for paternal treatment from the government."

"Reforms? In what sense?"

“For example, more respect for a man's dignity, more security for the individual, less force in the armed forces, fewer privileges for that corps which so easily abuses what it has."

"Elias," answered the youth, "I do not know who you are, but I suspect that you are not a man of the people; you think and act so differently from others. You will understand me if I tell you that, however imperfect the condition of affairs maybe now, it would be more so if it were changed. I might be able to get the friends that I have in Madrid to talk by paying them; I might even be able to see the Captain-General, but neither would the former accomplish anything nor has the latter sufficient power to introduce so many novelties. Nor would I ever take a single step in that direction, for the reason that, while I fully understand that it is true that these corporations have their faults, they are necessary at this time. They are what is known as a necessary evil." ${ }^{31}$

Here Elias pronounces himself as the leader and representative of the oppressed. He enumerates the institutions that cause cancer in society. He wants radical reforms - a total wipeout of these abusive institutions. On the other hand, Ibarra, aside from not believing that Elias is the right person to represent the oppressed, would only propose reforms as institutions themselves are necessary to have a concrete society. Since Ibarra was also aware of the evils created by these institutions, he named themnecessary evils.

Another interesting conversation between the two can be found in Chapter L Elias's Story:

"My friend, neither you nor I, although we may wish it, can accomplish this."

"Alone, it is true, we are nothing, but take up the cause of the people, unite yourself with the people, be not heedless of their cries, set an example to the rest, spread the idea of what is called a fatherland!"

"What the people ask for is impossible. We must wait."

"Wait! To wait means to suffer!"

${ }^{31}$ Rizal, The Social Cancer, 311-312. 
"If I should ask for it, the powers that be would laugh at me."

"But if the people supported you?"

"Never! I will never be the one to lead the multitude to get by force what the government does not think proper to grant, no! If I should ever see that multitude armed, I would place myself on the side of the government, for in such a mob, I should not see my countrymen. I desire the country's welfare; therefore, I would build a schoolhouse. I seek it by means of instruction, by progressive advancement; without light, there is no road." ${ }^{32}$

Elias is encouraging Ibarra - "unite yourself with the people...spread the idea of what is called fatherland." This can be interpreted as the planned action of revolution with the use of people power. But Ibarra did not heed the advice. He remained with his idea that the solution can be found in educating the people- "therefore, I would build a schoolhouse. I seek it by means of instruction..." Crisostomo Ibarra challenged the belief of Elias, but in the end, they just reconciled by admitting the differences of their beliefs.

However, what is more interesting was the shift of these two characters towards the end of the story. Elias, after learning that Ibarra's grandfather was the cause of his family's misfortunes, saved Ibarra (instead of killing him), redeeming himself and his family in ending the curse. Here, the capability of Elias to be violent was altered with his strong set of morals. On the other hand, Ibarra met many misfortunes. Among these was when Father Salvi plotted a fake rebellion against the Civil Guards and pointed Ibarra as the leader of the revolt. Because of this, Ibarra had to escape. Fortunately, Elias was there to ride him a boat for his escape, and on this part of the novel, we can now see the shifting between the characters. In Chapter LXI The Chase on the Lake, Elias is convincing Ibarra not to draw violence:

\begin{abstract}
"You are the master of your own will, sir, and of your future," he said to Crisostomo, who had remained silent. "But if you will allow me an observation, I would say: think well what you are planning to do-you are going to light the flames of war, since you have money and brains, and you will quickly find many to join you, for unfortunately there are plenty of malcontents. But in this struggle you are going to undertake, those who will suffer most will be the defenseless and the innocent. The same sentiments that a month ago impelled me to appeal to you asking for reforms are those that move me now to urge you to think well. " 33
\end{abstract}

Ibarra turned into a rebellious character that would now resort to violence. He will convince Elias to join him, but the former will refuse the offer. Ibarra insisted that his decision to go with violence was final and firm and would not think if many innocent people will suffer. On this part of the conversation, Ibarra was sure about his decision:

"Then, I'll go on without you!" Responded Ibarra resolutely.

\footnotetext{
${ }^{32}$ Rizal, The Social Cancer, 325.

${ }^{33}$ Rizal, The Social Cancer, 396-397.
} 
"Is your decision final?"

"Final and firm; let the memory of my mother bear witness! I will not let peace and happiness be torn away from me with impunity. I who desired only what was good, I who have respected everything and endured everything out of love for a hypocritical religion and out of love of country. How have they answered me? By burying me in an infamous dungeon and robbing me of my intended wife! No, not to avenge myself would be a crime; it would be encouraging them to new acts of injustice! No, it would be cowardice, pusillanimity, to groan and weep when there is blood and life left, when to insult and menace is added mockery. I will call out these ignorant people, and I will make them see their misery. I will teach them to think not of brotherhood, but only that they are wolves for devouring; I will urge them to rise against this oppression and proclaim the eternal right of man to win his freedom!"

"But innocent people will suffer!"34

Through their conversation, we learn that Elias is capable of conceiving a more general sense of freedom. Ibarra is bound to his country through class interest; his patriotism comes from having enjoyed privileges. ${ }^{35}$ Towards the end, Elias will die with Sisa, and Basilio, one of her sons, will witness this. The shifting of the characters becomes interesting towards the sequel El Filibusterismo. Thirteen years after that fateful moment, Ibarra would return as Simoun with the features of being revolutionary and ready to cast violence for his revenge.

Tasyo is another interesting character in Noli Me Tangere. For Carlos Quirino, this character alludes to no other than Rizal's older brother, Paciano. In the novel, Tasyo was named "the philosopher" because of his background as a former student of philosophy who would have to give up his career in obedience to his mother's wishes; the poor woman feared that if her son became learned, he would forget God. ${ }^{36}$ He was vulgarly called pilosopo under the same atmosphere that occasioned the prejudice of mixing up the fool and the sage. ${ }^{37}$ Tasyo was the original character in Noli who wished to establish a school for the community. When he met Ibarra, the first advice that Tasyo gave was to proceed with the plan in the context of political consideration. He is also the character who had a fierce battle against superstition. His first discourse is on Purgatory, a doctrine which he considers spurious and has spawned simoniacal practices such as the sale of Masses, indulgences, and religious objects. ${ }^{38} \mathrm{He}$ and Elias are the characters that in Noli that would constantly remind Ibarra that his plans will not work out because they have observed that Ibarra confuses social ends with individual purpose. Despite this common observation and significant influence on Ibarra, it would be interesting to note that these two characters never met in the story. Tasyo will die in the Noli but would have his thoughtfulness sustained, and perhaps even developed in the Fili as Padre Florentino.

\footnotetext{
${ }^{34}$ Rizal, The Social Cancer, 397.

${ }^{35}$ Daroy, "European Liberalism," 146.

${ }^{36}$ Daroy, "European Liberalism" 131.

${ }^{37}$ Pascual, "Interpretation of Rizal," 84.

${ }^{38}$ Bonoan, "Rizal's Prophetic Vision," 2.
} 
Fathers Damaso and Salvi also played vital roles in the novel. Salvi's character will sustain up to the sequel El Filibusterismo. These two are good examples of the early missionaries and the succeeding missionaries. The early missionaries were brusque, crude, and actual participants in the building of and struggles in the life of the people. In contrast, the later missionaries were pre-occupied with the preservation of the gains already attained by the former. ${ }^{39}$ Damaso and Salvi violated their vows of poverty and chastity; as Damaso sexually assaulted Pia Alba that led to her pregnancy and the birth of Maria Clara, while Salvi, faked a revolution against the Civil Guards and pointed Ibarra as the leader to get the attention of Maria Clara and frustrate her in their plans of getting married. Padre Salvi for Quirino was the individual who could be linked to the gossip of nefarious ongoings at the Santa Clara nunnery. ${ }^{40}$ These two characters are said to be "cancerous" as they are part of the ills of the society.

Another interesting priest character is Padre Sybila that alludes to the vicerector of the pontifical university Bernardino Nozaleda who became Archbishop of Manila. ${ }^{41} \mathrm{His}$ appearances in the novels embarked on the first few chapters in the novel. He was described as intelligent, especially when correcting his friend, Padre Damaso.

Women characters are interpreted not to have redeeming value. Aside from Maria Clara, who had a tragic fate, there is the case of Sisa, who is popularly marked as the character who lost her sanity because of her sufferings. She was portrayed as a battered wife who lost her children Crispin and Basilio. Crispin would meet his death, and Basilio would find his mother already dying in the last part of the novel. Other female characters are similarly wretched. Doña Consolacion's role was that of a former laundrywoman-turned wife of the alferez but was never attributed any value by her husband. Pia Alba was abused by a friar and had a child with him. There is also Doña Victorina - the victorious because she was able to marry a Spaniard. She treats herself as one of the important people in society. Victorina, as described by Hornedo, is "reflecting in her total vanity the discourse of her time, pretended the truths of her time." ${ }^{42}$ These portrayals of women in the society will continue in the Fili, Rizal, probably not to underestimate them, but to present the actual state of women in the country. As Hornedo notes, "But no matter. A woman is building his dream right now." ${ }^{43}$

In shifting to El Filibusterismo, the characters of Simoun, Padre Florentino, and Basilio are interesting in Rizal's quest to cure cancer. In Noli Me Tangere, the cancer he presented can be attributed as malignant. But in the Fili, Rizal will try to portray what could be the best cure. The transformation of Crisostomo Ibarra into Simoun in the Fili is part of the liberal argument that Rizal presents in the two novels. ${ }^{44}$ In the character of Simoun (originally Ibarra), Rizal portrayed a bittersweet return to San Diego as Simoun relinquished his memories in the town thirteen years ago. His character represents an individualistic trait and not a hero to save the community. In the person of Simoun, therefore, Rizal had the dramatis persona, which would signify an error from the

\footnotetext{
${ }^{39}$ Pascual, "Interpretation of Rizal," 81.

${ }^{40}$ Quirino, "Noli and Fili," 136.

${ }^{41}$ Quirino, "Noli and Fili" 136.

${ }^{42}$ Hornedo, "Creating an Idiom," 83.

${ }^{43}$ Hornedo, "Creating an Idiom," 87.

${ }^{44}$ Daroy. "European Liberalism," 152.
} 
individualistic point of view. ${ }^{45}$ The person of Simoun, in the Fili, shifted the issue of liberalism from institutional relations to the relationship between the individual and institutions. ${ }^{46}$

Basilio, on the other hand, was the child left towards the end of the story in Noli. In the story, he went to Capitan Tiago and offered his services in order to survive. Later, he was matriculated by Tiago. In the Fili, Basilio is already a medical student, full of hopes and dreams. The character of Basilio symbolizes the youth of the nation. $\mathrm{He}$ is the only person who has known the revolutionary plans of Simoun. Although Simoun features individualistic traits in Fili, in Chapter VII Simoun, Simoun and Basilio's conversation reveals Rizal's patriotic ideals. Again, these are the ideas previously presented between Ibarra and Elias in Noli. It reads:

\begin{abstract}
"Ah, youth is ever inexperienced and dreamy, always running after the butterflies and flowers! You have united so that by your efforts, you may bind your fatherland to Spain with garlands of roses when in reality, you are forging upon it chains harder than the diamond! You ask for equal rights, the Hispanization of your customs, and you do not see that what you are begging for is a suicide, the destruction of your nationality, the annihilation of your fatherland, the consecration of tyranny! What will you be in the future? A people without character, a nation without liberty-everything you have will be borrowed, even your very defects! You beg for Hispanization and do not pale with shame when they deny it to you! And even if they should grant it to you, what then-what have you gained? At best, a country of pronunciamentos, a land of civil wars, a republic of the greedy and the malcontents, like some of the republics of South America! To what are you tending now, with your instruction in Castilian, a pretension that would be ridiculous were it not for its deplorable consequences! You wish to add one more language to the forty-odd spoken in the islands, so that you may understand one another less and less." 47
\end{abstract}

Simoun here is very revolutionary, selfless, again a manifestation of Rizal's political ideologies. But in that conversation, Basilio will argue with Simoun that the youth, although leaning towards social fabrication (Hispanization), have the right to choose a particular "labor." In his case, he chose to devote himself to science.

"No, no, sir!" replied Basilio modestly, "I'm not folding my arms, I'm working like all the rest to raise up from the ruins of the past a people whose units will be bound together-that each one may feel in himself the conscience and the life of the whole. However, enthusiastic our generation may be, we understand that there must be a division of labor in this great social fabric. I have chosen my task and will devote myself to science." ${ }^{48}$

Simoun disagrees with Basilio, pointing out that science may only offer a remedy to ease a human's life. In other words, man uses science by just seeking their welfare. But Basilio will continue to defend science as it is more human and universal.

\footnotetext{
${ }^{45}$ Daroy, "European Liberalism," 154

${ }^{46}$ Daroy, "European Liberalism," 153.

${ }^{47}$ Rizal, The Reign of Greed, 48-49.

${ }^{48}$ Rizal, The Reign of Greed, 51.
} 
In the continuation of their conversation:

\begin{abstract}
"Science is more eternal, it's more human, it's more universal!" exclaimed the youth in a transport of enthusiasm. "Within a few centuries, when humanity has become redeemed and enlightened when there are no races when all peoples are free, when there are neither tyrants nor slaves, colonies nor mother countries, when justice rules and man is a citizen of the world, the pursuit of science alone will remain, the word patriotism will be equivalent to fanaticism, and he who prides himself on patriotic ideas will doubtless be isolated as a dangerous disease, as a menace to the social order." ${ }^{\prime 9}$
\end{abstract}

Then Simoun will counter the words of Basilio. At this moment, he will remind the youth of the realities that he cannot recognize because he only focused on his privileges given to him by his fate and told him that his arguments could only be acceptable if the society knows how to value humanity. As Simoun implied:

\begin{abstract}
"Simoun smiled sadly. "Yes, yes," he said with a shake of his head, "yet to reach that condition it is necessary that there be no tyrannical and no enslaved peoples, it is necessary that man goes about freely, that he knows how to respect the rights of others in their individuality, and for this there is yet much blood to be shed, the struggle forces itself forward." 50
\end{abstract}

If we are going to interpret this, the lines of Simoun were very patriotic, and his words founded with deep and strong ideology on what should be the fate of the country. Nevertheless, towards the end of the Fili, his plan would fail because another important character in the story will reveal why his planned revolution should fail. This is in the character of Padre Florentino.

In real life, Padre Florentino alludes to the former parish priest of Calamba, Father Leoncio Lopez. ${ }^{51}$ His appearance in the Fili can be found in the first chapter; he was among those passengers in the steamer Tabo but was placed in the lower deck. It can be said that Florentino is the new Tasio in Fili. Padre Florentino was beset by a spiritual crisis when his former fiancée married a worthless fellow in despair. To save himself from spiritual dissolution, he dedicated himself wholeheartedly to his priestly work among the people and, not unlike the philosopher, cultivated his love for the natural sciences. ${ }^{52}$ In many ways, Padre Florentino is Tasio redivivus, the philosophe who was coming back to life. Like Tasio, he is a wise old man and bears the marks of the Enlightenment: he is a lover of science; in fact, the study of the natural sciences saves him from spiritual dissolution. ${ }^{53} \mathrm{His}$ character will be more significant in the last chapter of Fili when Simoun confessed to him after the authorities ran after him. All the plans of Simoun should fail, and Padre Florentino had his answer:

"God will forgive you, Señor... Simoun, he said. "He knows that we are fallible. He has seen that you have suffered, and in ordaining that the chastisement for your

\footnotetext{
${ }^{49}$ Rizal, The Reign of Greed, 51.

${ }^{50} \mathrm{Rizal}$, The Reign of Greed, 51-52.

${ }^{51}$ See Carlos Quirino's “Noli and Fili: Their Historical Authenticity." Historical Bulletin 7 (June 1963).

${ }^{52}$ Bonoan, "Rizal's Prophetic Vision," 3.

${ }^{53}$ Bonoan, "Rizal's Prophetic Vision," 11.
} 
faults should come as death from the very ones you have instigated to crime, we can see His infinite mercy. He has frustrated your plans one by one, the best conceived, first by the death of Maria Clara, then by a lack of preparation, then in some mysterious way. Let us bow to His will and render Him thanks!" ${ }^{54}$

Then it is in Padre Florentino's character where Rizal placed his idea on why and how the revolution should fail. Simoun's intentions must fail because it will cause trouble and chaos among people. As Padre Florentino continues:

"You fostered the social rottenness without sowing an idea. From this fermentation of vices, loathing alone could spring, and if anything were born overnight, it would be at best a mushroom, for mushrooms only can spring spontaneously from filth. " ${ }^{\circ 5}$

Here, the social rottenness fostered by Simoun was his plan of a revolution. That was a product of his vengeance to those who stripped him of privileges, liberty, and happiness-in short, that revolution had no clear ideology. After that, Padre Florentino stressed:

\begin{abstract}
"Señor Simoun, when our people is unprepared, when it enters the fight through fraud and force, without a clear understanding of what they are doing, the wisest attempts will fail, and better that they do fail, since why commit the wife to the husband if he does not sufficiently love her if he is not ready to die for her?"56
\end{abstract}

If one enters or decides to spark the flames of the revolution, it is important that the people clearly understand what they are fighting for and who will benefit from their efforts. A real revolutionist knows how to take care and handle the situation. If it lacks preparation, then it is better yet to fail. Moreover, when Padre Florentino now heeds the youth of the nation, he mentioned:

"Pure and spotless must the victim be that the sacrifice may be acceptable!"57

There must be a purity of the nation; even then, the revolution might succeed. Towards the end, Padre Florentino held the treasure chest of Simoun, went to the cliff and threw it towards the sea. In his last words, Padre Florentino discarded the idea of Revolution but never abandoned its possibility in the future, as he said:

"May Nature guards you in her deep abysses among the pearls and corals of her eternal seas," then said the priest, solemnly extending his hands. "When for some holy and sublime purpose, a man may need you, God will in his wisdom, draw you from the bosom of the waves. Meanwhile, there you will not work woe, you will not distort justice, you will not foment avarice!"58

\footnotetext{
${ }^{54}$ Rizal, The Reign of Greed, 296.

${ }^{55}$ Rizal, The Reign of Greed, 298.

${ }^{56}$ Rizal, The Reign of Greed, 299.

${ }^{57}$ Rizal, The Reign of Greed, 300.

${ }^{58}$ Rizal, Reign of Greed, 301.
} 
At this point, we can say that Rizal rejected the idea of Revolution. However, he was not totally against it, nor would he abandon its possibilities. From the flow of the story, he pointed out that for a revolution to succeed, a nation must first subscribe to the following: first, there should be a clear ideology; next, there should be enough preparation; and finally, there should be a purity of the nation. If these three are absent, then a revolution would not be enough for the nation.

As Daroy said, "the end of Fili, therefore, which thwarts the revolution plotted by Simoun, should not be taken to mean as a total rejection of revolution or the individualistic liberal point of view. Far from being a rejection of revolution, the ending of El Filibusterismo merely points to the motives, method, and justifications which make revolution an inevitable failure." ${ }^{59}$ Coinciding with what Unamuno observed on Rizal, "he was not a supporter of Philippine independence; this clearly follows in all his writings. This he never advocated because he did not believe that his country was prepared for independent nationhood, believing that Spain should provide the protection and patronage that she needed until she reached the age of emancipation." 60 So for Rizal, there is a perfect time for the revolution. That time is yet to be determined until all the Filipinos learn from its past and become enlightened to the realities that make the society, which until now suffers from the social ills-social cancer.

\section{Epilogue}

The novels of Rizal revealed many aspects and points of reflection about Philippine society. Particularly in Noli Me Tangere, Rizal was doing critical hermeneutics. The whole novel can be viewed as a critique of Filipinos' cultural values in Rizal's time with an implied analysis of social systems and a prophetic vision. ${ }^{61}$ Aside from the characters that presented institutions and allusions, Rizal also presented the Filipino values in his novels, particularly in Noli Me Tangere. He brought out the religiosity of the Filipinos mixed up with superstitions that eventually leads to fanaticism and fatalism (i.e., to let the wheel of fate alone determine their destiny). Rizal also cited family values as well as the obsession of the Filipinos to be classy or sosyal. You have there the social climber like Victorina, Tiago, a wealthy person but ignorant of his worth because keeping the people ignorant was the best way to be controlled by the Spaniards. This also cites the habit of the amplification of personalities but not focusing on the real issues in society or ideas. Furthermore, of course, Rizal could never forget about the Filipino's insensitivity, passivity, and apathy.

Given these points, Rizal was very effective in portraying the Philippine society. The allegorical phasing of the characters, places, and situations magnified the sociopolitical condition of the country under Spain. He used in his novels his language-the medical language. With the application of his passion for philosophy and influences from liberalism in Europe, he put Noli Me Tangere as his diagnosis to the social ills that turned out as the Social Cancer. The characterization he used in the story will give you the idea of what could be the best cure for it. Hence, El Filibusterismo would contain his

${ }^{59}$ Daroy, "European Liberalism," 158.

60Unamuno, "Tagalog Hamlet," 9.

${ }^{61}$ Manuel B. Dy, Jr. "Noli Me Tangere: A Critical Hermeneutics.” The Noli Me Tangere A Century After: An Interdisciplinary Perspective (1987): 91. 
prescription. After a long battle in choosing between reform and revolution, in the end, Rizal chose liberty through reforms.

I would agree that these two novels can be attributed to containing his version of the philosophy of history because he used these works to propel his desire for an advanced society and culture by using the institutions, even if in conflict with one another, progress may be possible. As Schumacher said: "as long as the writings of Rizal continue to be read, and Filipinos continue to reflect on the kind of society their forefathers wanted to create, Rizal's thoughts will continue to be subversive of all societies which fail to bring justice and freedom to the Filipino people. ${ }^{62}$ Given all of these, the researcher contends that Jose Rizal, one of the greatest Filipinos of all time, was a great social portraitist in showing the history of the Philippine society of his time with the use of literary criticism.

${ }^{62}$ John Schumacher, S.J. "Rizal the Revolutionary and the Ateneo." Philippine Studies vol. 26 (3rd Quarter, 1978): 236. 


\section{REFERENCES}

Agoncillo, T. \& Alfonso, O. (1967). History of the Filipino People. Quezon City: Malaya Books.

Agoncillo, T.A. (2003). "Literature as History." in History and Culture, Language and Literature: Selected Essays of Teodoro A. Agoncillo, edited by Bernardita Reyes Churchill, 47-56. Manila: UST Publishing House. . (1978). "Prelude To A Revolution: Prosperity awakens the need for a civil rights struggle." In Filipino Heritage: The Making of a Nation, Vol. 7, edited by Alfredo R. Roces, 1877-1883. Manila: Lahing Pilipino Publishing.

. (2003). "The Historical Background of Philippine Literature." in History and Culture, Language and Literature: Selected Essays of Teodoro A. Agoncillo, edited by Bernardita Reyes Churchill, 81-111. Manila: UST Publishing House.

Arensmeyer, E. C. (1970). “Little Mansions: Some Aspects of Jose Rizal as a Novelist.” Philippine Studies, 18, (4), 740-752.

Bernad, M. A. (1987). "Humor and Craftsmanship in the Opening Chapters of the Noli." The Noli Me Tangere A Century After: An Interdisciplinary Perspective, Budhi Papers (7) 39-51.

Bonoan, R. J. (1987). "An Inquiry into Rizal's Prophetic Vision." The Noli Me Tangere A Century After: An Interdisciplinary Perspective, Budhi Papers (7) 1-16.

Daroy, P. (1965). "The Ideas of European Liberalism in the Fiction of Rizal." Philippine Social Sciences and Humanities Review (3) 109-183.

De Viana, A. (2012). Jose Rizal in Our Times: A Guide for the Better Understanding of the Philippines' Foremost National Hero. Manila: Books Atbp. Publishing.

Del Pilar, M. (2009). Frailocracy in the Philippines. Translated by Leonor Agrava. Manila: National Historical Institute.

Dy, M. B. Jr. (1987). “Noli Me Tangere: A Critical Hermeneutics.” The Noli Me Tangere A Century After: An Interdisciplinary Perspective, Budhi Papers (7) 89-95.

Guerrero, L.M. (1991). The First Filipino: A Biography of Jose Rizal. Quezon City: Printon Press.

Hornedo, F. H.. (1987). "Noli Me Tangere: Creating an Idiom to Legitimize a New Paradigm of Power." The Noli Me Tangere A Century After: An Interdisciplinary Perspective, Budhi Papers (7): 81-87.

Pascual, R. R. (1964). “Institutional Interpretation of Rizal's Novels.” University College Journal, (5-6) 78-85.

Quirino, C. (1963). "Noli and Fili: Their Historical Authenticity." Historical Bulletin (7) 132-137.

Rizal, Jose. (1974). The Reign of Greed. Translated by Charles Derbyshire. Manila: McCullough Printing Company.

Rizal, Jose. (1974). The Social Cancer. Translated by Charles Derbyshire. Manila: McCullough Printing Company.

Sancianco, G. (1975). The Progress of the Philippines. Translated by Encarnacion Alzona. Manila: National Historical Institute.

Schumacher, J. N. (1978). "Rizal the Revolutionary and the Ateneo." Philippine Studies. (26) 231-240.

Totanes, S.H.S. (1987). "The Historical Impact of Noli Me Tangere and the El Filibusterismo," The Noli Me Tangere A Century After: An Interdisciplinary Perspective, Budhi Papers (7) 17-27.

Unamuno, M. (1968). "Rizal: The Tagalog Hamlet.” Translated by Antonio Molina in Rizal: Contrary Essays, edited by Petronilo Daroy and Dolores Feria, 8-9. Quezon City: Guro Books.

Woods, D. (1991). "Racial Exclusion in the Mendicant Orders from Spain to the Philippines." UCLA Historical Journal (11). Retrieved from https://escholarship.org/uc/item/40b573nx. 